\title{
Colloquy
}

\section{MOURNING, AFFECT, SOCIALITY: On the Possibilities of Open Grief}

\author{
ZOËWOOL \\ Rice University \\ (iD https:/ / orcid.org/0000-0001-9534-2633
}

Grief is often rendered as central to sociality, an affective domain and set of practices in which our attachments to, care for, and investment in others are revealed in life's breach. Psychological approaches to grief generally take it to be a fundamental feature of life for us as an essentially social species, one that may have an evolutionary explanation (Archer 1999). Other approaches layer cultural specificity on top of this universal human account. Renato Rosaldo's (1993) "Grief and the Headhunter's Rage" constitutes one anthropological touchstone. And in his 1915 essay on war and death, Sigmund Freud notes that "mourning is regularly the reaction to the loss of a loved person" (Freud 1918, 243) and imputes the pain of grief to "primeval man" (Freud 1918, 293). He also calls "our complete collapse when death has struck down someone we love" part of a "cultural and conventional attitude toward death" (Freud 1918, 209).

This account of grief as variable but also essentially human appears within theories of other fundamental features of human social life, including vulnerability and kinship. Judith Butler (2006, 2015) describes vulnerability in Levinasian terms, as an openness to the other that is fundamental to ethical obligation and cohabitation. And take Marshal Sahlins's (2013, ix, 28; emphasis added) parsimoni- 
ous, lovely, and tempting formulation on the essence of kinship: Kinship is "living each other's lives and dying each other's deaths."

But what if the contours of one's capacities preclude the dying of another's death? What if one does not feel grief? Is a person ejected from the space of kinship altogether? Does a measure of invulnerability to grief diminish one's ability to be with others, to become with others, to make a world with them? That is the fear articulated to me by Jason, a U.S. veteran with severe traumatic brain injury (TBI) with whom I've worked for a year and a half, and who, by his own account, can no longer feel pain, loss, or grief. He says this condition makes him "less human.”

My effort to think through accounts in which feelings of grief appear as a kind of litmus test for human sociality, and thereby humanity itself, is caught by my niggling concern that such theories of grief contribute to a reading of disability - in particular of non-normative affective and cognitive modes of social engagement that are often read as disengagements (Baggs 2007)_ as something that imperils one's ability to be embedded in a social world, that such theories of grief contribute to the dehumanization of disability (cf. Taylor 2017). So I wonder if such theories of grief, with their alignments of mourning, affect, and sociality, might not be too strong, and if the practice of making a careful ethnographic account might require, or better yet, might help generate weaker theory, theory that is better suited to what Lisa Stevenson $(2020,9)$ in this collection calls, following Roland Barthes (1981), "the impossible science."

In referring to a "weak theory" here I am invoking Eve Kosofsky Sedgwick's (2003) elaboration of Silvan S. Tomkins's (2008) work on strong versus weak affect theories. Sedgwick $(2003,134)$ notes that strong theory has "reach and reductiveness - that is . . conceptual elegance - involving both assets and deficits." While strong theories allow for broad generalizations (like, "kinship is living each other's lives and dying each other's deaths"), they may fail to account for any given case. Weak theories, on the other hand, do not allow for broad generalizations. They “account only for 'near' phenomena” (Tomkins 2008, 433; see also Sedgwick 2003, 134), but always do so effectively. In an ongoing attempt to account for forms of care that are bound to death in various non-normative ways that I encounter in my fieldwork with veterans - and in an awkward position in which my own conceptual (and political and ethical) work around disability is challenged by the normativity that structures the desires of my interlocutors in the field - I find myself reaching for the weakest of theories to account for the contradictory nature of such experiences, a weakness difficult but necessary to maintain in the face of 
death, a phenomenon that draws one forcefully into the realm of the universal and leaves perplexing particulars unaccounted for.

The first time I met Jason, he told me that his brain injury had left him without feelings. I thought he was referring to the fact that he has no sensation and limited motor control on one side of his face and body. But then, as evidence of this problem of not feeling, Jason said, "I couldn't even cry when my dad died." I found myself disoriented. I hadn't known his father was dead, and was thrown off kilter by the news of a parent's untimely death delivered so starkly, as a fact unburdened by the weight and affective trappings that such a death would usually carry - be they sadness, bitterness, stoicism, or even gallows humor. It became clear that physical sensation was not the kind of feeling Jason was concerned about having lost.

In the same sparse and unaffected way, Jason went on to tell me the story of his father's death: It was three years after Jason's injury. His father had been away on business, had gone missing, and then had been found shot in the head. "We'll never really know what happened," Jason said to me, his affect and speech unchanged, reiterating, "I couldn't even cry."

I awkwardly attempted to explain away Jason's problematization of non-feeling by validating it as an experience of mourning in its own right. This proved a failed gesture of care on my part, one that refused to recognize, or perhaps more modestly to hold, the intractability of Jason's predicament of non-grief. He insisted that he could not feel anything, and without feeling, he could not mourn, and without mourning, he had no "closure," an unsettling openness redoubled in his assertion that "we'll never really know what happened."

This conversation has stayed with me in part because of my own disorienting shock at learning of this tragic death without any of the usual affective and communicative registers that not only cushion the communication of such a difficult event but that also perform the embeddedness of such a death within a world of social intimacy, attachment, and care, registers that would transform it from the affectively dry space of forensics ("just the facts") to the emotionally thick world of the familial (the facts of life and death). In other words, one reason this encounter stayed with me was because of the way it disoriented my own normative expectations about affect in the context of (familial) grief. While the encounter proved disorienting to me, the lack of feeling was (and remains) disorienting to 
Jason: his non-feeling was a key marker of his own disorientation in the aftermath of his injury.

As I've come to learn, this disorientation is anomalous for him. Jason usually says he is quite satisfied with his life and the contours of his capacities. He is mostly accustomed to and unconcerned by the effects of his TBI. Though he frequently finds himself physically disoriented in space-having difficulty with mobility, proprioception, and navigation - he is not usually off kilter in the more existential way induced by his incapacity to feel the pain of grief.

I think here of Sara Ahmed's $(2006,159)$ contention that "disorientation involves becoming an object," rather than being a body involved in the world. Jason has settled into his physical disorientation. When he has gotten lost mere blocks from his home, even when he loses his balance and falls, his sense of being in the world does not come unmoored. Yet, as he describes it, the particular affective disorientation of not feeling his father's death does precisely undermine his involvement in the world. If affect is the capacity to affect and be affected and, through that capacity, a becoming in (and making) the world with others (Deleuze and Guattari 1987; cf. Leys 2011), if emotion is fundamental to the making (and governance) of the social (Lutz 1988; Ahmed 2014, 10), what if the affective channels and emotional genres that communicate and confer certain fundamental feelings are unavailable?

Though his affect is altered, Jason has told me that his feelings remain there, except "the ability to cry and mourn." He tells me he wishes he could have feelings of grief - for his father, for his many friends who have died. Not having them, he says, "makes me less human." He recalls his father's funeral where everyone but he was in tears. He admits this non-feeling makes him "feel left out," makes him sense he's "not able to be like everybody else should be." "That kind of stuff," he says, referring to the pain of loss, "is necessary." We might call this a kind of alienation. A becoming object, rather than being a body involved in the world. Jason's concern about his inability to mourn registers a concern about his inability to be attached, an incapacity to performatively enact the vulnerabilities of intimacy and "withness" (Desjarlais 2016, 116-17) in the space of mourning that thereby calls into question the existence of these attachments at all. For Jason, in losing these feelings, something necessary has been lost, bringing him to the limits of humanity. Jason insists on a strong theory. 
It seems relatively uncontroversial to say that the strongest of all theories of grief belongs to Freud (1957), who distinguishes mourning, in which the lost object is separated from oneself and let go, from melancholia, in which the object is incorporated into oneself such that the object of loss may in fact be unclear and the attachment to grief does not subside. This central distinction is immeasurably helpful for understanding the normative politics of affect in the face of death in the cultural context of secular liberalism. ${ }^{1}$ Because of that normative force, some writing about Black, postcolonial, and other forms of life positioned outside the charmed circle of liberalism's worthy lives have critically situated themselves within the pathologized space of melancholia, making claims, as Angela Garcia (2010) has, for melancholic subjectivity, or, as Joseph R. Winters (2016) has, for a "hope draped in black" that entails a melancholy disposition with regard to progress.

But there also exist reasons to think such forms of life away from this distinction. For example, in her trenchant and haunting In the Wake: On Blackness and Being, Christina Sharpe (2016) works through figurations of transatlantic slavery - the wake, the hold, the weather - to render the density of Black being amid ongoing and histories of anti-Blackness. It is a powerful book of life and death that refuses the diagnostic categories of normative grief altogether. Freud makes not a single appearance. In response to Sharpe's work, the question of delineating healthy and pathological grieving seems absurd. For one, it eschews strong theory in favor of ramifying echoes that refuse to be stilled into objects of perfectible knowledge. What Sharpe's $(2016,17)$ work offers is not knowledge of being in the wake but an "orthography" that preforms "wake work," a method Sharpe calls, specifically, "unscientific." Hers is a decolonial project that resonates, perhaps somewhat surprisingly, with Barthes's (1981) impossible science (cf. Stevenson 2020, 9). We might say that what both projects have in common is an insistence that projects of perfect knowledge are antithetical to the care called forth by grief.

And perhaps here is a way out of the seeming dilemma of non-grief, a way of holding non-grief, rather than knowing it; a way to refuse a strong theory of grief suggesting that if we cannot die another's death, we cannot belong to each other, suggesting that the absence of grief, or of its legible, normative performance, ejects one from the category of the human. After all, though it is not much discussed, even Freud, the strong theorist of grief par excellence, confessed to not grieving the death of his much-beloved mother (Lehmann 1983; Jonte-Pace 2001; Spreng- 
nether 2018). Perhaps we can find our way, ethnographically, or orthographically, or ontographically, to a weaker place where, in a gesture of care, we do not reach toward the contours of the human at all. In an effort to move away from questions of pathology and the human, and to do so in a way that can still hold - rather than explain away - the truth of Jason's own account of his experience, I have begun to feel out the contours of a weak theory bound to open grief.

Alongside Jason's insistence on the necessity of grief stands the unsettling openness produced by its absence. Rather than reading that unsettled openness as a sign of pathological attachment, or as an account of the pathology of Jason's injury, we might find in it a space to reckon with non-normative affects of care (cf. Piepzna-Samarasinha 2018). In the disorientation that comes from occupying the indeterminate space of open grief, Jason — who has little conventional capacity for self-reflection - is reckoning with the difference that comes from the realignments of care, attachment, and affect brought about by his injury. From that, his desire for pain and feelings of loss emerges. And so perhaps an analytic of open grief leads us not toward the human, and not toward the pathological, but toward a way of thinking about care as a longing for the feeling of loss. This would constitute a weak theory that does not operate with closure as a normative value, and does not assume the traumatic nature of openness. In such a weak theory, the feeling of not feeling might be the feeling of becoming object at the same time as it might be an opening to reckon with alter-affects of care. This, I think, would constitute a modest and disorienting analytical space for thinking about care and death, one that would not offer solid ground on which to fix humanity and sociality, nor a certainty about how or if they ought to be affixed to each other. But perhaps such disorientation is exactly what is needed.

\begin{abstract}
This essay examines mourning and the possibilities for open grief among veterans, asking how the traces of what has been lost persist into the present in ways that find no easy resolution. It questions the normative value of an end to mourning, proposing instead that grief - and indeed our anthropological formulations of the meaning of such affects and events - might be held open, trace and memory maintained, imagining recognition as something open-ended that might recast discomfort as the potential for a different kind of sociality. [affect; mourning; veterans]
\end{abstract}

\title{
NOTES
}

Acknowledgments I gratefully acknowledge all the participants in the 2018 Wenner-Gren funded workshop on "Care at the Nexus of Power and Praxis," for which this piece was first 
drafted, as well as the participants in the 2019 "Bodies of Knowledge" seminar at Princeton, where a version of this material was presented, and the anonymous reviewers who made generous interventions. Thanks to Lauren Cubellis whose tremendous organizational efforts made this possible. This research was funded by NSF award \#1751639.

1. In Death without Weeping, the canonical anthropological example of non-feeling in the face of familial death, Nancy Scheper-Hughes (1989, 426-27) notes that experts made use of Freud's theory to pathologize poor Brazilian mothers' affectively neutral or positive responses to their infants' deaths and instruct them on supposedly healthy and appropriately modern forms of feeling and affect. The collection All the Weight of Our Dreams: On Living Racialized Autism (Brown, Ashkenazy, Giwa Onaiwu 2017) demonstrates how experiences of affective and neurological difference are also embedded in racialized and gendered affective norms.

\section{REFERENCES}

Ahmed, Sara

2006 Queer Phenomenology: Orientations, Objects, Others. Durham, N.C.: Duke University Press.

2014 The Cultural Politics of Emotion. 2nd ed. New York: Routledge.

Archer, John

1999 The Nature of Grief: The Evolution and Psychology of Reactions to Loss. New York: Routledge.

Baggs, Mel (Amanda)

2007 "In My Language." January 14. Video, 8:36. https://www.youtube.com/ Barthes, Roland watch? $\mathrm{v}=\mathrm{JnylM} 1 \mathrm{hI} 2 \mathrm{jc}$.

1981 Camera Lucida: Reflections on Photography. Translated by Richard Howard. New York: Hill and Wang

Brown, Lydia X. Z., E. Ashkenazy, and Morénike Giwa Onaiwu, eds.

2017 All the Weight of Our Dreams: On Living Racialized Autism. Lincoln, Neb.: DragonBee. Butler, Judith

2006 Precarious Life: The Powers of Mourning and Violence. New York: Verso.

2015 Notes toward a Performative Theory of Assembly. Cambridge, Mass.: Harvard University Press.

Deleuze, Gilles, and Félix Guattari

1987 A Thousand Plateaus: Capitalism and Schizophrenia. Translated by Brian Massumi. 2nd ed. Minneapolis: University of Minnesota Press.

Desjarlais, Robert

2016 Subject to Death: Life and Loss in a Buddhist World. Chicago: University of Chicago Press.

Freud, Sigmund

1918 Reflections on War and Death. New York: Moffat, Yard.

1957 "Mourning and Melancholia." In The Standard Edition of the Complete Psychological Works of Sigmund Freud Volume XIV, (1914-1916), 237-58. London: Hogarth and

Garcia, Angela Institute of Psycho-Analysis.

2010 The Pastoral Clinic: Addiction and Dispossession along the Rio Grande. Los Angeles: University of California Press.

Jonte-Pace, Diane

2001 Speaking the Unspeakable: Religion, Misogyny, and the Uncanny Mother in Freud's Cultural Texts. Berkeley: University of California Press.

Lehmann, Herbert

1983 "Reflections on Freud's Reaction to the Death of His Mother." Psychoanalytic Quarterly 52, no. 2: 237-49. https://doi.org/10.1080/21674086.1983.11927030. 
Leys, Ruth

2011 “The Turn to Affect: A Critique." Critical Inquiry 37, no. 3: 434-72. http://doi. org/10.1086/659353.

Lutz, Catherine A.

1988 Unnatural Emotions: Everyday Sentiments on a Micronesian Atoll and Their Challenge to Western Theory. Chicago: University of Chicago Press.

Piepzna-Samarasinha, Leah Lakshmi

2018 Care Work: Dreaming Disability Justice. Vancouver: Arsenal.

Rosaldo, Renato

1993 Culture and Truth: The Remaking of Social Analysis. Boston: Beacon. Originally published in 1989.

Sahlins, Marshall

2013 What Kinship Is - And Is Not. Chicago: University of Chicago Press.

Scheper-Hughes, Nancy

1989 Death without Weeping: The Violence of Everyday Life in Brazil. Berkeley: University of California Press.

Sedgwick, Eve Kosofsky

2003 Touching Feeling: Affect, Pedagogy, Performativity. Durham, N.C.: Duke University Press.

Sharpe, Christina

2016 In the Wake: On Blackness and Being. Durham, N.C.: Duke University Press.

Sprengnether, Madelon

2018 Mourning Freud. New York: Bloomsbury Academic.

Stevenson, Lisa

2020 "Looking Away." Cultural Anthropology 35, no. 1: 6-13. https://doi.org/10.14506/ ca35.1.02.

Taylor, Sunaura

2017 Beasts of Burden: Animal and Disability Liberation. New York: New Press.

Tomkins, Silvan S.

2008 Affect Imagery Consciousness: The Complete Edition. New York: Springer.

Winters, Joseph R.

2016 Hope Draped in Black: Race, Melancholy, and the Agony of Progress. Durham, N.C.: Duke University Press. 